\title{
PENERAPAN MODEL INKUIRI UNTUK MENINGKATKAN HASIL BELAJAR POKOK BAHASAN KERJA SAMA NEGARA-NEGARA DI ASIA TENGGARA PADA MATA PELAJARAN PKn BAGI SISWA KELAS VI DI SDN TANJUNGREJO III TONGAS-PROBOLINGGO
}

\author{
Nur Khosiah \\ Pendidikan Dasar, Pascasarjana Universitas Negeri Surabaya
}

\begin{abstract}
Abstrak
Penelitian ini berawal dari rendahnya hasil belajar siswa kelas VI SDN Tanjungrejo III Tongas, Kabupaten Probolinggo. Hal ini yang melatar belakangi peneliti untuk melakukan penelitian dengan menggunakan model pembelajaran Inkuiri. Tujuan dari penelitian ini adalah untuk meningkatkan hasil belajar siswa pada mata pelajaran PKn di kelas VI SDN Tanjungrejo III Tongas Kabupaten Probolinggo.

Jenis penelitian yang digunakan adalah penelitian tindakan kelas (PTK) dengan metode deskriptif kualitatif. Subyek penelitian ini adalah siswa kelas VI SDN Tanjungrejo Tongas, Kabupaten Probolinggo dengan jumlah 34 siswa. Tehnik pengumpulan data yang digunakan adalah observasi untuk mengetahui aktivitas guru, aktivitas siswa, dan hasil belajar siswa pada saat kegiatan pembelajaran menggunakan model pembelajaran Inkuiri.

Hasil penelitian ini menunjukkan bahwa pembelajaran dengan menggunakan model Inkuiri dapat meningkatkan aktivitas guru, aktivitas siswa dan hasil belajar siswa. Hal ini terbukti hasil penelitian yang diperoleh pada setiap siklusnya. Pada siklus I aktivits guru mencapai $75 \%$, aktivitas siswa $68,3 \%$ dan hasil belajar siswa mencapai kognitif mencapai $68 \%$, afektif mencapai 72,2\% dan psikomotor mencapai $77 \%$. Pada siklus II aktivitas guru mencapai $78 \%$, aktivitas siswa $78 \%$ dan hasil belajar siswa kognitif $82 \%$, afektif $84 \%$, psikomotor $79 \%$. Pada siklus III aktivitas guru mencapai $88 \%$, aktivitas siswa $85 \%$ dan hasil belajar siswa kognitif $88 \%$, afektif $86 \%$, psikomotor $85 \%$. Maka dapat disimpulkan bahwa penerapan pembelajaran Inkuiri yang dilaksanakan dalam pembelajaran PKn pada pokok bahasan kerja sama negara-negara di Asia Tenggara dapat meningkatkan aktivitas guru, aktivitas siswa dan hasil belajar siswa kelas VI di SDN Tanjungrejo, Tongas, Kabupaten Probolinggo.
\end{abstract}

Kata Kunci: Model Ikuiri, Hasil Belajar, PKn Sekolah Dasar

\begin{abstract}
This study originated from the low class VI student learning outcomes SDN Tanjungrejo III Tongas, Probolinggo. This is the background for researchers to conduct research using inquiry learning model. The purpose of this research is to improve student learning outcomes in subjects Civics in class VI SDN Tanjungrejo III Tongas Probolinggo.

This type of research is classroom action research (PTK) with descriptive qualitative method. The subjects of this study were students of class VI SDN Tanjungrejo Tongas Probolinggo the number of 34 students. Data collection techniques used were observation to determine the activity of the teacher, student activities, and student learning outcomes at the time of learning activities using inquiry learning model.

These results indicate that by using a model of inquiry learning can enhance the activity of the teacher, student activities and student learning outcomes. This proved to the research results obtained in each cycle. In the first cycle activity teachers reached $75 \%, 68.3 \%$ of student activity and student learning outcomes reached cognitive reached $68 \%$, reaching $72.2 \%$ affective and psychomotor reached $77 \%$. in the second cycle of activity reached $78 \%$ of teachers, $78 \%$ of student activity and student learning outcomes of cognitive $82 \%, 84 \%$ affective, psychomotor $79 \%$. the third cycle of activity reached $88 \%$ of teachers, $85 \%$ of student activity and student learning outcomes of cognitive $88 \%, 86 \%$ affective, psychomotor $85 \%$. It can be concluded that the application of Inquiry learning is implemented in becancluded Civics on the subject of work in Southeast Asia countries can enhance the activity of the teacher, student activities and student learning outcomes class VI SDN Tanjungrejo, Tongas, District Probolinggo.
\end{abstract}

Keywords: Inquiry Model, Learning Outcomes, Elementary School, Civics

\section{PENDAHULUAN}

Pendidikan Pancasila dan Kewarganegaraan yang sesuai dangan isi kurikulum 2006 adalah pendidikan tentang nilai-nilai yang sasarannya bukan hanya pengalihan pengetahuan saja melainkan ditekankan pada pembentukan sikap. Dengan demikian mata pelajaran PKn meliputi ranah afektif, psikomotor, kognitif, yang lebih menitik beratkan pada ranah afektif. Kepribadian siswa pada hakikatnya dipengaruhi oleh ketiga 
ranah afektif, psikomotor, kognitif. Ketiga ranah tersebut sulit dipisahkan satu dengan yang lainnya, sehingga membentuk kepribadian yang unik pada setiap manusia. Dalam menyajikan pembelajaran, guru harus mengembangkan ketiga ranah tersebut agar sesuai dengan apa yang diharapkan. Dalam pelaksanaan pembelajaran terdapat perbedaan tergantung ranah mana yang mendapat penekanan, sementara dalam pembelajaran PKn, hasil akhir yang menjadi tujuan adalah pengembangan ranah afektif yang sesuai dengan nilai dan norma yang berlaku dan berkembang dalam tatanan kehidupan manusia Indonesia.

Dalam proses pembelajaran $\mathrm{PKn}$, guru belum semuanya pendekatan siswa aktif, dan peranan guru sebagai dinamisator belajar siswa belum di terapkan, namun guru masih dominan menggunakan metode melaksanakan ceramah dan tanya jawab. Untuk menumbuhkan sikap aktif, kreatif, inovatif, dari siswa tidaklah mudah. Fakta yang terjadi adalah guru dianggap sebagai sumber belajar yang paling benar. Disisi lain rendahnya hasil belajar siswa pada mata pelajaran PKn merupakan salah satu indikasi pembelajaran yang dilakukan guru perlu dicermati lebih serius lagi. Hal yang sering dijumpai dalam suatu pembelajaran mengakibatkan rendahnya prestasi siswa di antaranya: (1) kegiatan pembelajaran masih didominasi oleh guru; (2) rendahnya semangat belajar siswa; (3) banyaknya siswa yang tidak berani bertanya atau mengemukakan pendapat; (4) metode pembelajaran yang digunakan kurang bervariatif (monoton); (5) media pembelajaran yang tidak sesuai; (6) Tidak berorientasi pada kebutuhan masyarakat setempat. Menghadapi permasalahan ini dibutuhkan sebuah solusi untuk menciptakan suasana penbelajaran yang memudahkan siswa untuk berperan lebih aktif, kreatif dan mengesankan, apalagi sekolah- sekolah di daerah pedesaan agar pemikiran mereka berkembang dan tidak bergantung pada guru saja akan tetapi dapat menemukan pembaharuan atau ide-ide baru dari pemikiran mereka sendiri. Salah satu solusi untuk mengatasi permasalahan ini adalah pembelajaran dengan penerapan model inkuiri.

Penerapan model inkuiri sangat penting karena akan menghasilkan peserta didik yang mampu memecahkan masalah-masalah. Sejalan dengan hal ini Tisngatun Nurrahmah (2008:81) mengemukakan bahwa salah satu cara yang dapat mendorong siswa untuk terlibat secara aktif dalam menemukan konsep pada proses belajar mengajar yaitu dengan melakukan pembelajaran menggunakan model inkuiri.

Menurut Sanjaya (2010:195) Pembelajaran inkuiri menekankan pada proses mencari dan menemukan. Materi pelajaran tidak diberikan secara langsung. Peran siswa dalam strategi ini adalah mencari dan menemukan sendiri materi pelajaran. Sedangkan guru berperan sebagai fasilitator dan pembimbing siswa untuk belajar.

Berdasarkan uraian yang telah dikemukakan pada latar belakang masalah maka rumusan masalah dalam penelitian ini adalah sebagai berikut: (1)Bagaimana aktivitas siswa selama mengikuti proses pembelajaran melalui penerapan model inkuiri pada mata pelajaran PKn, (2) Bagaimana aktivitas guru dalam pembelajaran melalui penerapan model inkuiri pada mata pelajaran PKn, (3) Bagaimana hasil belajar siswa melalui penerapan model inkuiri pada mata pelajaran PKn.

Berdasarkan rumusan masalah tersebut di atas maka dapat diuraikan tujuan penelitian adalah sebagai berikut: (1)Untuk mendeskripsikan aktivitas siswa selama mengikuti proses pembelajaran melalui penerapan model inkuiri, (2) Untuk mendeskripsikan aktivitas guru selama dalam pembelajaran melalui penerapan model inkuiri, (3) Untuk mendeskripsikan hasil belajar siswa yang mengikuti proses pembelajaran melalui penerapan model inkuiri.

Menurut Setiavana (2013:87)Pembelajaran inkuiri juga merupakan kegiatan pembelajaran yang melibatkan secara maksimal seluruh kemampuan siswa untuk mencari dan menyelidiki sesuatu (benda, manusia, atau peristiwa) secara sistematis, kritis, logis, dan analitis, sehingga ia mampu merumuskan sendiri penemuannya dengan penuh percaya diri. Sedangkan pendapat dari Anderson (2002) menyatakan dengan pendekatan inkuiri untuk proses belajar mengajar di kelas mengharuskan guru terbiasa dengan model pembelajaran inkuiri dan implementasinya di dalam kelas karena inkuiri melibatkan semua siswa, guru hanyalah sebagai fasilitator.

Tabel 1. Sintak Model Belajar Melalui Penemuan

\begin{tabular}{ll}
\hline Tahap & Tingkah Laku Guru \\
\hline Tahap 1 & Guru menyajikan kejadian- \\
Observasi untuk & kejadian atau fenomena \\
menemukan & yang memungkinkan siswa \\
masalah & menemukan masalah. \\
Tahap2 & Guru membimbing siswa \\
Merumuskan & merumuskan masalah \\
Masalah & penelitian berdasarkan \\
\hline
\end{tabular}




\begin{tabular}{|c|c|}
\hline & $\begin{array}{l}\text { kejadian dan fenomena } \\
\text { yang disajikan. }\end{array}$ \\
\hline Tahap 3 & Guru membimbing siswa \\
\hline Mengajukan & mengajukan \\
\hline hipotesis & $\begin{array}{l}\text { hipotesis terhadap masalah } \\
\text { yang telah dirumuskan }\end{array}$ \\
\hline Tahap 4 & Guru membimbing siswa \\
\hline Merencanakan & untuk merencanakan \\
\hline pemecahan & pemecahan \\
\hline masalah & menyiapkan \\
\hline (melalui & bahan yang \\
\hline $\begin{array}{l}\text { eksperimen atau } \\
\text { cara lain) }\end{array}$ & $\begin{array}{l}\text { diperlukan dan menyusun } \\
\text { prosedur kerja yang tepat. }\end{array}$ \\
\hline Tahap 5 & Selama siswa bekerja guru \\
\hline Melaksanakan & membimbing \\
\hline $\begin{array}{l}\text { eksperimen (atau } \\
\text { cara pemecahan }\end{array}$ & ilitasi \\
\hline $\begin{array}{l}\text { masalah yang } \\
\text { lain) }\end{array}$ & \\
\hline Tahap 6 & membantu \\
\hline Melakukan & pengamatan \\
\hline pengamatan dan & hal-hal yang \\
\hline pengumpulan data & $\begin{array}{l}\text { penting dan membantu } \\
\text { mengumpulkan }\end{array}$ \\
\hline & mengorganisasi data \\
\hline Tahap 7 & Guru membantu siswa \\
\hline Analisis data & $\begin{array}{lr}\text { menganalisis data } & \text { supaya } \\
\text { menemukan } & \text { sesuatu } \\
\text { konsep } & \end{array}$ \\
\hline Tahap 8 & Guru membimbing siswa \\
\hline Penarikan & mengambil \\
\hline kesimpulan & berdasarkan \\
\hline atau & menemukan sendiri konsep \\
\hline penemuan & yang ingin ditanamkan. \\
\hline
\end{tabular}

Keunggulan Inkuiri

Strategi Pembelajaran inkuiri memiliki beberapa keunggulan, di antaranya:

a. Pembelajaran yang menekankan kepada pengembangan aspek kognitif, afektif, dan psikomotor secara seimbang, sehingga pembelajaran melalui inkuiri ini dianggap lebih bermakna

b. Memberikan ruang kepada siswa untuk belajar sesuai dengan gaya belajar mereka.

c. Pembelajaran ini dianggap sesuai dengan perkembangan psikologi belajar modern yang menganggap belajar adalah proses perubahan tingkah laku berkat adanya pengalaman.

d. Keuntungan lain dari strategi pembelajaran ini dapat melayani kebutuhan siswa yang memiliki kemampuan di atas rata-rata. Artinya, siswa yang memiliki kemampuan belajar bagus tidak akan terlambat oleh siswa yang lemah dalam belajar.
Djamarah dan Zain (1997:23) menyatakan bahwa metode inkuiri mempunyai kelebihan dan kekurangan yaitu sebagai berikut:

a. Hasil belajar dengan cara inilebih mudah dihafalan dan diingat, mudah ditransfer untuk memecahkan masalah.

b. Pengetahuan dan kecakapan anak didik bersangkutan lebih jauh dapat menumbuhkan motivasi intrinsik, karena siswa dapat merasa atas penggunaannya sendiri.

Sedangkan kelemahannya sebagai berikut:

a. Kalau kurang terpimpin atau kurang terarah dapat menjurus pada kekacauan dan kekaburan materi yang dipelajari.

b. Memakan banyak waktu.

\section{METODE}

Jenis penelitian yang dilakukan merupakan penelitian tindakan kelas yang dilaksanakan 4 tahap kegiatan yaitu: perencanaan, pelaksanaan tindakan, observasi, dan refleksi. Keempat tahap kegiatan tersebut dilaksanakan dalam bentuk siklus pembelajaran.

\section{Perencanaan (Planning)}

Kegiatan ini dimulai dengan merumuskan rancangan tindakan pembelajaran yaitu: (1) menyusun rencana pelaksanaan pembelajaran, yang meliputi standar kompetensi, kompetensi inti, penyusunan indikator, menetapkan materi pembelajaran, menyusun kegiatan, memilih dan menetapkan media dan sumber pembelajaran, (2) menyusun diskriptor dan kriteria pembelajaran pelaksanaan inkuiri, (3) menyusun instrument berupa : lembar observasi, lembar angket dan alat evaluasi untuk mengukur hasil belajar siswa.

2. Pelaksanaan tindakan (Action)

Kegiatan pelaksanaan pembelajaran di kelas dan pelaksanaan tindakan yang dilakukan oleh peneliti sebagai upaya membangun pemahaman konsep siswa serta mengamati hasil atau dampak dari diterapkannya tindakan tersebut.

Rencana penelitian yang telah disusun tersebut akan diaplikasikan oleh guru dalam proses pembelajaran. Adapun kegiatan yang dilakukan pada tahap ini adalah melaksanakan pembelajan yang telah disusun dalam silabus.

3. Observasi (Observation)

Pengamatan terhadap tindakan pembelajaran PKn di kelas VI dengan penerapan model inkuiri dilakukan bersaman dengan pelaksanaan tindakan. Hal ini dilaksanakan secara intensif, 
obyektif, dan sistematis. Pengamatan dilakukan oleh guru dan teman sejawat pada waktu peneliti melaksanakan tindakan pembelajaran PKn.

Dalam kegiatan ini peneliti, guru dan teman sejawat (observer) berusaha mengenal dan mendokumentasikan semua indikator dari proses hasil perubahan yang terjadi baik yang disebabkan oleh tindakan maupun dampak intervensi dalam pembelajaran PKn berdasarkan penerapan model inkuiri. Keseluruhan hasil pengamatan ditulis dalam bentuk lembar pengamatan.

4. Refleksi (reflection)

Tahapan ini dimaksudkan untuk mengkaji atau menganalisis secara menyeluruh tindakan yang telah dilakukan berdasarkan data yang telah terkumpul dari hasil pengamatan selama tindakan dilakukan. Setelah dianalisis hasil pengamatan tersebut, selanjutnya dievaluasi tentang kekurangan yang perlu diperbaiki dalam pelaksanaan setiap siklus, dan menguraikan juga mengenai kelebihannya sehingga dari uraian tersebut dapat dijadikan untuk tindakan pada siklus selanjutnya.

\section{Indikator Keberhasilan}

Untuk mengukur keberhasilan penelitian menggunakan keberhasilan indikator. Indikator keberhasilan penelitian :

1. Penelitian dikatakan berhasil dalam proses pembelajaran apabila aktivitas guru meliputi: menggali ide siswa, membimbing siswa menyusun hipotesis, membimbing siswa menguji hipotesis dengan melakukan pengamatan, membimbing siswa diskusi kelompok, menugaskan siswa membuat laporan hasil kerja kelompok, menugaskan siswa mempresentasikan hasil kerja kelompok, dan membimbing siswa membuat kesimpulan mencapai keberhasilan $\geq 80 \%$.

2. Penelitian dikatakan berhasil dalam proses pembelajaran apabila aktivitas siswa meliputi: merumuskan pertanyaan sesuai dengan masalah, menyusun hipotesis, menguji hipotesis dengan pengamatan, melakukan diskusi kelompok, membuat laporan hasil kerja kelompok, membuat kesimpulan mencapai keberhasilan $\geq$ $80 \%$.

3. Hasil belajar siswa dianggap tuntas apabila secara individu pada hasil evaluasi memeroleh nilai $\geq 65$. Sedangkan ketuntasan klasikal tercapai apabila seluruh siswa dalam kelas tersebut tuntas belajarnya sebanyak $\geq 80 \%$.

\section{Hasil Tindakan Kelas Siklus I}

1. Data Observasi Aktivitas Guru

Aspek-aspek yang diamati untuk aktivitas guru pada pelaksanaan pembelajaran PKn dengan menerapkan model inkuiri siklus I.

Kegiatan pembelajaran yang mendapat nilai rata-rata 3 dengan kriteria "Baik" pada saat menggali ide siswa untuk merumuskan pertanyaan. Membimbing siswa menyusun hipotesis mendapat nilai rata-rata 2,5 , aspek lain yang memperoleh nilai 3 adalah membimbing siswa menguji hipotesis dengan melakukan pengamatan, Aspek membimbing membimbing siswa diskusi kelompok untuk menganalisis data hasil pengamatan mendapat rata-rata 2,5,Aspek kelima menugaskan siswa membuat laporan hasil kerja kelompok, menugaskan siswa mempresentasikan hasil kerja kelompok, dan aspek yang tertinggi membimbing siswa membuat kesimpulan mendapat nilai rata-rata 4. Meski Aktivitas guru dalam pembelajaran inkuiri siklus I ini masih mendapat predikat baik namun belum memenuhi keberhasilan ketuntasan standar yang telah ditentukan oleh peneliti dan guru kelas VI yaitu sebesar $80 \%$.

2. Data Aktivitas Siswa

Data Hasil Observasi Aktivitas Siswa dengan Penerapan Inkuiri.

\begin{tabular}{|c|c|c|c|c|c|}
\hline \multirow{2}{*}{ No } & \multirow{2}{*}{$\begin{array}{l}\text { Aspek yang } \\
\text { diamati }\end{array}$} & \multicolumn{2}{|c|}{ Observer } & \multirow{2}{*}{$\begin{array}{l}\text { Rat } \\
\text { a- } \\
\text { rat } \\
\text { a }\end{array}$} & \multirow{2}{*}{$(\%)$} \\
\hline & & O1 & O2 & & \\
\hline 1 & $\begin{array}{l}\text { Merumuskan } \\
\text { pertanyaan } \\
\text { sesuai } \\
\text { dengan } \\
\text { masalah }\end{array}$ & 2.38 & 2.47 & 2.43 & 60,75 \\
\hline \multirow[t]{2}{*}{2} & $\begin{array}{l}\text { Menyusun } \\
\text { hipotesis }\end{array}$ & 2.55 & 2.41 & 2.48 & 62 \\
\hline & $\begin{array}{l}\text { Menguji } \\
\text { hipotesis }\end{array}$ & 2.94 & 2.79 & 2.86 & 71 \\
\hline 3 & $\begin{array}{l}\text { dengan cara } \\
\text { melakukan } \\
\text { pengamatan }\end{array}$ & & & & \\
\hline 4 & $\begin{array}{l}\text { Melakukan } \\
\text { diskusi } \\
\text { kelompok } \\
\text { untuk } \\
\text { menganalisis } \\
\text { data }\end{array}$ & 3.00 & 2.94 & 2.96 & 74 \\
\hline 5 & $\begin{array}{l}\text { Membuat } \\
\text { laporan hasil } \\
\text { kerja }\end{array}$ & 3.00 & 2.94 & 2.96 & 74 \\
\hline
\end{tabular}


Dari tabel di atas belum mencapai standar keberhasilan yang telah ditentukan yaitu $80 \%$

3. Data Hasil Belajar Siswa

dapat diketahui evaluasi hasi belajar pada siklus I dari 34 siswa, 23 siswa berhasil mencapai ketuntasan dan 11 siswa masih belum tuntas. Persentase ketuntasan pada siklus I ini mencapai 74,35\%.

\section{Hasil Tindakan Siklus II}

1. Data Observasi Guru

Setelah diadakan perbaikan pada tindakan siklus II ini megalami peningkatan, dapat dilihat mengenai aspek yang diamati untuk aktivitas guru pada pelaksanaan pembelajaran PKn dengan menerapkan model inkuiri siklus II sebagai berikut:

Kegiatan pembelajaran yang mendapat nilai rata-rata 3 dengan kriteria "baik" pada saat menggali ide siswa untuk merumuskan pertanyaan, membimbing siswa menyusun hipotesis, membimbing siswa menguji hipotesis dengan melakukan pengamatan, membimbing siswa diskusi kelompok untuk menganalisis data hasil pengamatan, menugaskan siswa membuat laporan hasil kerja kelompok. Sedangkan menugaskan siswa mempresentasikan hasil kerja kelompok 3.5 dan membimbing siswa membuat kesimpulanmendapat nilai tertinggi yaitu 4. Dalam siklus II ini proses pembelajaran aktivitas guru mengalami peningkatan dari pada siklus sebelumnya Karena guru sudah menerapkan pembelajaran inkuiri sesuai dengan sintak inkuiri dan siswa juga sangat antusias dalam mengikuti pembelajaran ini

2. Data Observasi Siswa

Data Hasil Observasi Aktivitas Siswa dengan Penerapan Inkuiri

\begin{tabular}{|c|c|c|c|c|c|}
\hline \multirow{2}{*}{$\begin{array}{l}\mathbf{N} \\
\mathbf{0}\end{array}$} & \multirow{2}{*}{$\begin{array}{l}\text { Aspek } \\
\text { diamati }\end{array}$} & \multicolumn{2}{|c|}{ Observer } & \multirow{2}{*}{$\begin{array}{l}\text { Rat } \\
\text { a- } \\
\text { rat } \\
\text { a }\end{array}$} & \multirow{2}{*}{$(\%)$} \\
\hline & & 01 & $\mathbf{O 2}$ & & \\
\hline 1 & $\begin{array}{l}\text { Merumuskan } \\
\text { pertanyaan } \\
\text { sesuai dengan } \\
\text { masalah }\end{array}$ & 3.29 & 3.26 & 3.28 & 82 \\
\hline 2 & $\begin{array}{l}\text { Menyusun } \\
\text { hipotesis }\end{array}$ & 3.12 & 3.12 & 3.12 & 78 \\
\hline 3 & $\begin{array}{l}\text { Menguji } \\
\text { hipotwsis } \\
\text { dengan cara } \\
\text { melakukan } \\
\text { pengamatan }\end{array}$ & 2.94 & 2.94 & 2.94 & 73,5 \\
\hline 3 & $\begin{array}{l}\text { Melakukan } \\
\text { diskusi } \\
\text { kelompok untuk } \\
\text { menganalisis } \\
\text { data }\end{array}$ & 3.00 & 3.12 & 3.06 & 76,5 \\
\hline 5 & $\begin{array}{l}\text { Membuat } \\
\text { laporan hasil } \\
\text { kerja kelompok }\end{array}$ & 3.12 & 3.12 & 3.12 & 76,5 \\
\hline 6 & $\begin{array}{l}\text { Mempresentasik } \\
\text { an laporan hasil } \\
\text { kerja kelompok }\end{array}$ & 3.29 & 3.26 & 3.28 & 82 \\
\hline \multirow[t]{4}{*}{7} & $\begin{array}{l}\text { Membuat } \\
\text { kesimpulan }\end{array}$ & 3.29 & 3.29 & 3.29 & $\begin{array}{l}82.2 \\
5\end{array}$ \\
\hline & Jumlah & $\begin{array}{l}22.0 \\
2\end{array}$ & $\begin{array}{l}22.1 \\
1\end{array}$ & $\begin{array}{l}22.0 \\
5\end{array}$ & \multirow{3}{*}{$\begin{array}{l}78.7 \\
5\end{array}$} \\
\hline & Rata-rata & 3.14 & 3.16 & 3.15 & \\
\hline & $\begin{array}{l}\text { Persentase } \\
\text { ketercapaian }\end{array}$ & $\begin{array}{l}78.6 \\
4\end{array}$ & $\begin{array}{l}78.9 \\
6\end{array}$ & $\begin{array}{l}78.7 \\
5\end{array}$ & \\
\hline
\end{tabular}

(Tuntas jika persentase keberhasilan $80 \%$ )

3. Data Hasil Belajar Siswa

dapat diketahui evaluasi hasi belajar pada siklus II dari 34 siswa, 28 siswa berhasil mencapai ketuntasan dan 6 siswa masih belum tuntas. Persentase ketuntasan pada siklus II ini mencapai 78,67 \%. Pada siklus ini telah berhasil namun kurang sedikit lagi mencapai persentase ketuntasan yang telah di tetapkan yaitu $80 \%$,

\section{Hasil Tindakan Kelas Siklus III}

1) Hasil Observasi Aktivitas Guru

Setelah diadakan perbaikan pada siklus III ini mengalaami peningkatan yang sangat memuaskan mencapai 89,3\%. Hasil tersebut telah mencapai persentase ketercapaian yang telah ditentukan yaitu $80 \%$. Dari tabel dapat dilihat mengenai aspek yang diamati untuk aktivitas guru pada pelaksanaan pembelajaran PKn dengan menerapkan model inkuiri siklus III sebagai berikut:

Kegiatan pembelajaran yang mendapat nilai rata-rata 3.5 dengan kriteria "baik" . Aspek 
yang memperoleh nilai rata-rata 3 dalam siklus ini, yaitu, membimbing siswa menguji hipotesis dengan melakukan pengamatan, membimbing siswa diskusi kelompok untuk menganalisis data hasil pengamatan,membimbing siswa menggali ide untuk merumuskan masalah menugaskan siswa membuat laporan hasil kerja kelompok mendapatkan skor rata-rata 4. Sedangkan menugaskan siswa mempresentasikan hasil kerja kelompok,membimbing siswa membuat kesimpulan mendapatkan skor rata-rata 4 yang merupakan nilai tertinggi.

2) Data Aktivitas Siswa

Data Hasil Observasi Aktivitas Siswa dengan Penerapan Inkuiri

\begin{tabular}{|c|c|c|c|c|c|}
\hline \multirow{2}{*}{$\begin{array}{l}\mathbf{N} \\
\mathbf{0}\end{array}$} & \multirow{2}{*}{$\begin{array}{l}\text { Aspek } \\
\text { diamati }\end{array}$} & \multicolumn{2}{|c|}{ Observer } & \multirow{2}{*}{$\begin{array}{l}\text { Rat } \\
\text { a- } \\
\text { rat } \\
\text { a }\end{array}$} & \multirow{2}{*}{$(\%)$} \\
\hline & & 01 & $\mathbf{O 2}$ & & \\
\hline 1 & $\begin{array}{l}\text { Merumuskan } \\
\text { pertanyaan } \\
\text { sesuai dengan } \\
\text { masalah }\end{array}$ & 3.41 & 3.44 & 3.42 & $\begin{array}{l}86.2 \\
5\end{array}$ \\
\hline 2 & $\begin{array}{l}\text { Menyusun } \\
\text { hipotesis }\end{array}$ & 3.12 & 3.38 & 3.25 & $\begin{array}{l}81.2 \\
5\end{array}$ \\
\hline 3 & $\begin{array}{l}\text { Menguji } \\
\text { hipotwsis } \\
\text { dengan cara } \\
\text { melakukan } \\
\text { pengamatan }\end{array}$ & 3.29 & 3.38 & 3.34 & 83.5 \\
\hline 4 & $\begin{array}{l}\text { Melakukan } \\
\text { diskusi } \\
\text { kelompok untuk } \\
\text { menganalisis } \\
\text { data }\end{array}$ & 3.38 & 3.38 & 3.38 & 84.5 \\
\hline 5 & $\begin{array}{l}\text { Membuat } \\
\text { laporan hasil } \\
\text { kerja kelompok }\end{array}$ & 3.50 & 3.50 & 3.50 & 87.5 \\
\hline 6 & $\begin{array}{l}\text { Mempresentasik } \\
\text { an laporan hasil } \\
\text { kerja kelompok }\end{array}$ & 3.44 & 3.38 & 3.41 & $\begin{array}{l}85.2 \\
5\end{array}$ \\
\hline 7 & $\begin{array}{l}\text { Membuat } \\
\text { kesimpulan }\end{array}$ & 3.44 & 3.50 & 3.47 & $\begin{array}{l}86.7 \\
5\end{array}$ \\
\hline & Jumlah & 23.58 & $\begin{array}{l}23.9 \\
6\end{array}$ & $\begin{array}{l}23.7 \\
7\end{array}$ & $\begin{array}{l}84.8 \\
9\end{array}$ \\
\hline & Rata-rata & 3.37 & 3.42 & 3.95 & \\
\hline & $\begin{array}{l}\text { Persentase } \\
\text { ketercapaian }\end{array}$ & 84.25 & 85.5 & $\begin{array}{l}84.8 \\
9\end{array}$ & \\
\hline
\end{tabular}

(Tuntas jika persentase keberhasilan $80 \%$ )

3) Data Hasil Belajar Siswa

Dapat diketahui evaluasi hasi belajar pada siklus III dari 34 siswa, 30 siswa berhasil mencapai ketuntasan dan 4 siswa masih belum tuntas akan tetapi persentase ketuntasan pada siklus III ini mengalami ketuntasan karena sudah mencapai $88.23 \%$. Dan ini telah melampaui persentase ketuntasan keberhasilan yang telah ditetapkan yaitu oleh peneliti dan guru kelas VI yaitu sebesar $80 \%$.

\section{KESIMPULAN DAN SARAN}

Berdasarkan hasil penelitian tindakan kelas dan pembahasan dalam penelitian ini dapat dikemukakan kesimpulan sebagai berikut:

1. Aktivitas guru dalam pelaksanaan pembelajaran dengan menerapkan model inkuiri pada setiap siklusnya menunjukkan peningkatan. Peningkatan tersebut berdampak positif terhadap tercapainya setiap komponen pembelajaran. Siklus I memperoleh persentase sebesar $75 \%$, siklus II memeroleh persentase sebesar $80,35 \%$, dan siklus III memeroleh persentase sebesar $88,3 \%$.

2. Aktivitas siswa pada penelitian ini secara umum dari seluruh aspek menunjukkan peningkatan, karena smua aspek terlaksana dengan baik. Pada siklus I memeroleh persentase sebesar $68,25 \%$, siklus II memeroleh persentase $78,75 \%$, sedangkan siklus III memeroleh $84,89 \%$.

3. Hasil belajar siswa dari mulai siklus I hingga siklus III dengan menerapkan model inkuiri menunjukkan peningkatan.Siklus I hasil belajar kognitifnya 67,64\%, dan hasil belajar afektifnya $72,2 \%$, serta Psikomotornya $77,2 \%$. Pada siklus II hasil belajar kognitifnya, $82,25 \%$, afektifnya $84,95 \%$, psikomotornya $79,04 \%$. Sedangkan siklus III hasil kognitifnya mencapai $88,23 \%$, afektifnya $85,82 \%$, dan psikomotornya $84,92 \%$. Dengan demikian hasil di setiap siklusnya selalu mengalami peningkatan.

Berdasarkan diskusi hasil penelitian dan pengalaman selama penelitian, maka peneliti dapat memberi saran-saran sebagai berikut:

1. Berdasarkan hasil belajar yang telah dicapai dengan menerapkan model inkuiri dapat juga dijadikan alternatif untuk diimplementasikan di sekolah dasar pada materi yang berbeda dan relevan menggunakan perangkat yang lebih baik.

2. Sebaiknya dalam pembelajaran PKn siswa sering dilibatkan salah satunya dengan memanfaatkan media gambar, membuat kliping,dengan harapan untuk menciptakan situasi pembelajaran yang menyenangkan, melatih kreatifitas siswa berdiskusi, 
meningkatkan rasa ingin tahu untuk berfikir kritis, kreatif dan inovatif.

3. Pada pembelajaran inkuiri kekurangan siswa dalam menyimpulkan, disarankan guru harus menjelaskan secara rinci agar dapat membuat kesimpulan

4. Berdasarkan pelaksanaan pembelajaran siklus I,II,dan III maka penggunaan media sabaiknya tidak monoton, namun harus di sesuaikan dengan materi ajar

1. Hambatan-hambatan yang muncul dalam pembelajaran sebaiknya dapat diminimalisir dengan menerapkan suatu model yang tepat salah satunya adalah model inkuiri.

\section{DAFTAR PUSTAKA}

Anderson,- Krathwohl. (2001). A Taxonomy For leaning, Teaching and Assessing: A Revision of Bloom's Taxonomy of Education Objectives. New York: Longman.

Barbara Striping. (2011). Inquiry:Inquiring Minds Want To Know.New York.

Djamarah, BS dan Zain.(1997). Strategi Belajar Mengajar, Jakarta: PT Rineka Cipta.

Darmadi Hamid. (2007). Pengantar Pendidikan Kewarganegaraan: Bandung: . Alfabeta.

Danil Callison. (2011). Inquiry Models. New York.

Faturrahman P, Sutikno Sobry. (2010). Strategi Belajar Bandung: Refika Aditama

Fajar, Arnie. (2004). Portfolio dalam pembelajaran IPS. Bandung: PT Remaja Rosdakarya.

Gulo, W. (2008). Strategi Belajar Mengajar. Jakarta: Grasindo.

Hamalik, Oemar. (2004). Proses Belajar Mengiajar. Jakarta: Bumi Aksara.

Hamalik, Oemar. (2010). Psikologi Belajar Dan Mengajar. Bandung: Sinar Baru Algensindo.

Haryani, Mimin.(2007). Model dan Teknik Penilaian Tingkat Satuan Pendidikan. Jakarta : Gaung Persada Press.

Hergenhahn. (2009). Theories of learning. Jakarta: Prenada Media Group.

Gonzales,J,J.(2013). My Journey inqury-based learning-journal on Excelence in college teaching.24(2),33-50.

Ibrahim, M. (2005). Assesment Berkelajutan, Surabaya: Unesa University Press.

Iskandar. (2012). Penelitian Tindakan Kelas. Jakarta: GP Press Group.

I Nyoman Sutama, I.B.Putu. A.,I.B. Jelantik.S. (2014). Pengaruh Model Inkuiri Terhadap Ketrapilan berfikir Kritis dan Kinerja Ilmiah
Pada Mata Pelajaran Biologi kelas IX SMA Negeri 2 Amlapura. Universitas Ganesha. Vol. 4.

Depdiknas. (2008). Kamus Besar Bahasa Indonesia Edisi 4. Jakarta: PT Gramedia Pustaka Utama.

Depdikbud. (1994). Kurikulum Pendidikan Dasar. Jakarta. Depdikbud.

Kemmis and Mc Taggart. (1988). Action Researech A Story Modern History.

Kosasih, Djahiri. (2006). Pendidikan Nilai Moral Dalam Dimensi Pendidikan Kewarganegaraan. Bandung: Laboratorium PKn FPIPs-UPI.

Kimberly Linerberger. (2014). Training The Foot Soldier Of Inquiry Development and Evaluation Of Graduete Teaching Asisten Learning Community. Vol.44, No. 1.

Koelan \& Achmad Zubaidi. (2007). Pendidikan Kewarganegaraan untuk Perguruan Tinggi. Yogyakarta: Paradigma.

Kazempour Mahsa, Amirshokoohi Aidin. (2014).Transitioning to inquiry-based teaching: exploring science teachers'. Vol.9,285-309.

Kong,S.C \& Song, Y. (2004). The Import of A Princip-based pedagogigcal design On Inquiry Based Learning is A Seamless Learning Enviranment In Hongkong Educational Tehnology \& Society, 17, (2). 127-141.

Leslie B Preddy. (2011). Student Inquiry In The Research Process. New York.

Marlina. (2000).Pengembangan perangkat pembelajaran berorientasi pendekatan penemuan. Tesis PPs Unesa.

Mulyasa, E. (2006). Menjadi guru profesional. Bandung: Remaja Rosda Karya.

Marjorie L. (2006). Primary Sources Inquiry Learning. New York.

Mario Maeots, Margus Pedaste(2014). The Role Of General Inquiry Knowledgein Enhancing Students, Transformative Processes in a web- Based Learning Environment. Vol 13, No 1.

Riyanto, Yatim.(2003). Metodologi pendidikan. Surabaya: SIC.

Rizema, Stiatava. (2013). Desain Belajar Mengajar Berbasis Sains. Jakarta: Diva press.

Ratumanan Gerson Tanwey. (2004). Belajar Dan Pembelajaran: Unesa University Press 